\title{
9. In search of a European legislative approach to adaptation to climate change
}

\section{Andrea Keessen}

\section{INTRODUCTION}

The European Union has started to plan for adaptation to climate change. ${ }^{1}$ It is acting on the IPCC Assessments reports warning that climate change is already happening. Warming is evident from observations of increases in global average air and ocean temperatures, widespread melting of snow and ice and rising global sea levels. ${ }^{2}$ And while there is no conclusive evidence, extreme events like the 2003 heatwave in Europe and hurricane Sandy in New York City in 2012 appear to be linked to climate change. ${ }^{3}$ As science now stands, the increase of the global average temperature is concluded to be very likely caused by anthropogenic greenhouse gas emissions. ${ }^{4}$

In view of the potential impacts of climate change, it is obvious that mitigation is essential. However, it is controversial how aggressive mitigation efforts should be ${ }^{5}$ and who should bear them. ${ }^{6}$ Hence not enough resources might be invested in abating greenhouse gas emissions. ${ }^{7}$ Moreover, even if humanity were able to halt emissions and stabilise the current greenhouse gas concentrations in the near future, warming and sea level rise would continue for centuries, due to the

\footnotetext{
http://climate-adapt.eea.europa.eu, accessed 26 November 2013.

IPCC Fourth Assessment Report 2007.

Jacob and Van den Hurk (2009); Grinsted et al (2013).

IPCC Fourth Assessment Report 2007.

Mendelsohn (2008).

6 As shown by the not universal ratification of the 1997 Kyoto Protocol and the slow progress in negotiating a new policy for the post 2012 period.

7 Diets and Stern (2008), in particular 101.
} 
timescales and feedbacks. ${ }^{8}$ Therefore, mitigation should be complemented by adaptation.

Both the Commission and the Council endorsed the idea that climate change policies need to have two legs: mitigation and adaptation. ${ }^{9}$ The EU already has a mitigation policy and has attempted to lead in setting mitigation targets. ${ }^{10}$ By contrast, the EU has been slow in developing an adaptation strategy. This difference might be an issue of scale. While mitigation requires a concerted, global effort to become effective, adaptation predominantly takes place at the local level because the impacts of climate change vary considerably, just like the potentially adequate responses. ${ }^{11}$ Yet these scalar differences should not be over-emphasised. ${ }^{12}$ Mitigation is implemented at the local level and local adaptation efforts can benefit from strategic guidance at higher levels. Moreover, linking mitigation and adaptation is expected to increase the effectiveness of both responses to climate change. ${ }^{13}$

The call of Article 3 of the UN Framework Convention to adapt to climate change is directed at governments. Many European countries have already developed national and regional adaptation strategies. ${ }^{14}$ This is an almost autonomous process, as there are only few binding EU rules in this field. Hence one reason for an EU adaptation strategy could be to create binding European rules which oblige all Member States to have adaptation strategies in place and can be enforced by the Commission However, the Commission has not yet opted for this course of action. Instead, the main reason for EU involvement is to contribute to the effectiveness of national and regional adaptation to climate change strategies. ${ }^{15}$

8 IPCC Fourth Assessment Report 2007.

9 Speech Connie Hedegaard, EU Commissioner for Climate Change, 8 July 2012, Cyprus informal meeting of Ministers for the Environment and Climate Change, Nicosia, Cyprus; Cyprus Presidency Concluding Remarks on the discussions on Adaptation on the 8th of July.

10 Schunz (2012); Schreurs (2007).

11 Termeer et al. (2011); Keessen et al. 2013.

12 Cole (2011).

13 For example, Becken (2005).

14 Biesbroek et al. (2010); http://climate-adapt.eea.europa.eu/web/guest/ countries, accessed 26 November 2013.

15 Adger et al. (2005). 
The European Commission adopted the EU adaptation strategy in April 2013. ${ }^{16}$ The Commission first proposed the EU approach to adaptation in the EU White Paper on Adaptation to Climate Change from 2009. Both the European Parliament and the Council expressed their agreement with this White Paper. ${ }^{17}$ The White Paper proposed four actions. The EU should build a knowledge base, mainstream adaptation into key policy areas, apply a combination of policy instruments (market-based instruments, guidelines, public-private partnerships) to ensure the effective delivery of adaptation, and coordinate international action. ${ }^{18}$ The Strategy focused on only three objectives in a different sequence. First: promoting action by the Member States, secondly: better informed decision making by addressing knowledge gaps, and thirdly: climate-proofing EU action: promoting adaptation in key vulnerable sectors by mainstreaming adaptation measures into EU policies. Although it no longer focuses on the instrumental part, the Strategy mentions various instruments, including European standards for energy, transport and buildings, providing financial support through EU funds, the website ClimateADAPT, and insurance. ${ }^{19}$

From a legal perspective, it is interesting to understand why the EU should become involved, whether and to what extent the EU has the competence to plan for adaptation and which approach the EU takes to embed adaptation measures in the current legal framework. In this regard it is particularly interesting whether the policy instruments to be used will also include binding rules which give rights to individuals and hence enable them to enforce before a court that their government takes measures to adapt to climate change. Questions pertaining to the external dimension of adaptation, for instance whether adaptation plays a role in EU neighbourhood policy, will not be addressed in this chapter.

16 Communication from the Commission to the European Parliament, the Council, the European Economic and Social Committee and the Committee of the Regions, An EU Strategy on adaptation to climate change, COM (2013) 216.

17 European Parliament, Non-legislative resolution of 6 May 2010 on the Commission White Paper: 'Adapting to climate change: Towards a European framework for action' (2009/2152(INI)), 06/05/2010, http://www.europarl.europa. eu/sides/getDoc.do?type=TA\&language $=$ EN\&reference $=$ P7-TA-2010-0154, accessed 26 November 2013.

18 White Paper Adapting to climate change: Towards a European Framework for Action, COM (2009) 147.

19 An EU Strategy on Adaptation to Climate Change, COM (2013) 216, 5, 7, 9. 


\section{WHY THE EU SHOULD BECOME INVOLVED}

The White Paper on Adaptation to Climate Change was the first decisive step in the development of an EU adaptation strategy. ${ }^{20}$ Both the Council and the European Parliament endorsed it. Subsequently, the European Commission stated in its Proposal for the 7th Environmental Action Plan (EAP) that action should be taken to ensure that the EU is adequately prepared for climate change because it is estimated that climate change will further aggravate environmental problems by causing prolonged droughts and heatwaves, floods, storms and forest fires, and new or more virulent forms of human, animal or plant diseases in Europe. ${ }^{21}$ Indeed adaptation to climate change is also part of the Europe 2020 Strategy, in order to arrive at a climate-resilient economy by $2050 .{ }^{22}$ The EU Adaptation Strategy of the European Commission warns that taking early, planned adaptation action to deal with unavoidable climate impacts will be cheaper than paying the price of not adapting. ${ }^{23}$

Adaptation to climate change is predominantly local in character, but that is not the only level for implementation of an adaptation policy. ${ }^{24}$ Adaptation is a multi-level effort which should be pursued at all levels, including the national and EU level. ${ }^{25}$ The EU can play a coordinating role when adaptation action or inaction has spatial impacts beyond the national borders. ${ }^{26}$ For example, a measure to combat coastal erosion can negatively impact neighbouring coastal areas. ${ }^{27}$ The EU can further complement the national policies of the Member States by enabling the systematic exchange of best practice on how to adapt to climate change, setting targets and by funding adaptation measures. ${ }^{28}$ Another important reason for EU involvement is to ensure that adaptation to climate change is addressed in the relevant EU policy areas. ${ }^{29}$ It is obvious that climate change affects agriculture, water, nature and energy, but adaptation to

20 It was preceded by a Green Paper on Adapting to Climate Change in Europe: Options for EU Action COM (2007) 354.

21 Proposal for the 7th EAP, 22; Ciscar (2009), p. 91.

22 European Commission (2010): "Communication on: EUROPE 2020, A strategy for smart, sustainable and inclusive growth". COM (2010) 2020, 16.

23 Adaptation Strategy, pp. 2-4.

24 Benson and Garmestani (2010), 2.

25 Rühl (2012); Benson and Garmestani (2010).

26 Adger et al. (2005).

27 Pethick and Crooks (2000).

28 Hanger et al. (under review); EU Adaptation Strategy, pp. 4 and 5.

29 See: http://ec.europa.eu/clima/policies/adaptation/index_en.htm, accessed 26 November 2013; Adaptation Strategy, pp. 8 and 9. 
climate change is important for other sectors as well, such as transport, construction, migration and health.

The need for mainstreaming or integration of adaptation and disaster risk management into EU policies depends on the impacts of climate change on the sector and the role of the EU in that sector. In some policies, the EU should be involved because of the cross-border impacts. This applies in particular to the water, energy and transport sector. In other policies, the main reason for EU involvement is the interdependency between Member States, which is reinforced by the creation of the internal market and the related free movement of goods, animals, plants and people. Finally, the extent of EU regulatory involvement necessitates including adaptation to climate change provisions into EU policies. This applies to common policies (fisheries, agriculture), the regulation of activities on the internal market (for example, building standards), but also to other policies, such as environmental legislation.

\section{EU COMPETENCE}

The idea proposed in the Adaptation Strategy, the White Paper and the proposal for the 7th EAP is to mainstream adaptation to climate change into all relevant EU policies. The White Paper foresees that this will be a long and continuous process. It appears from the White Paper that the mainstreaming of adaptation mainly requires a scientific and economic analysis to be successful. According to the White Paper, the key questions are: what are the actual and potential impacts of climate change in the sector, what are the costs of action or inaction, and how do proposed measures impact on and interact with policies in other sectors ${ }^{30}$ While the White Paper explains that adaptation options will vary by sector and highlights several policy sectors, it does not reflect on legal obstacles to mainstreaming.

The Adaptation Strategy remains silent on obstacles to mainstreaming, but limits the mainstreaming effort to key vulnerable sectors. Yet it does not define which sectors are these key vulnerable sectors. It lists policies where climate change is already taken into account in legislation and sectors where legislative proposals are tabled which integrate adaptation. ${ }^{31}$ It thus appears that mainstreaming does not take place in a very systematic way, but only when the occasion to integrate adaptation pops up. It also appears that the aim of the Strategy is limited as it announces

\footnotetext{
30 White Paper, 8.

31 Adaptation Strategy, 8.
} 
that moves to mainstream adaptation will be pursued in priority fields such as energy and transport. ${ }^{32}$ The Strategy considers that in health policy, measures and systems are already in place and only need to be adjusted to the challenges climate change may bring. ${ }^{33}$ It also emphasises infrastructure by announcing that climate change implications will be discussed with standardisation organisations, financial institutions and project managers responsible for infrastructure projects. ${ }^{34}$

From a legal perspective, what the EU can do to mainstream adaptation depends on its competence to act. ${ }^{35}$ Whether the law complicates mainstreaming depends on whether adaptation fits within the policy goals of a given EU policy. The legal situation is relatively uncomplicated when adaptation to climate change is in line with the policy goals of an EU policy. Then mainstreaming fits within the competence already bestowed on the EU in that policy field. In that case, mainstreaming adaptation into the policy can be done at the time the policy is up for revision. It is also possible that mainstreaming requires inserting adaptation provisions into legislation made for other purposes. That is not an unsurmountable hurdle. It is not uncommon to see EU legislation which serves more than one aim and this is accepted in the case law. ${ }^{36}$

Moreover, the Treaties explicitly allow for this option, as Article 11 TFEU (ex Article 6 EC) gives the EU the competence to integrate environmental concerns into other policies. Article 192(1) TFEU can provide an adequate legal basis for EU legislation, in so far as adaptation to climate change falls under the environmental policy of the EU. Perhaps such a clear link with environmental policy is not always present. For instance adapting building standards to improve the isolation and hence cold and heat resistance of buildings will also increase the energy efficiency of the building. It can thus be framed as both an adaptation and a mitigation measure with clear environmental benefits. However, adapting building standards can also be framed as a measure to harmonise standards on the internal market. Then no additional legal basis would be required for the insertion of such standards, thus facilitating the implementation of this adaptation measure.

It also depends on the competences of the EU in each policy field to what extent the EU can impose adaptation obligations. This applies both

\footnotetext{
32 Ibid.

33 Ibid.

34 Ibid.

35 For example, Knook (2004).

36 For example, Emiliou (1994).
} 
to adaptation measures which serve and those which do not serve an environmental interest. A few examples best illustrate the differences in what the EU can do depending on the varying degrees of competence. For instance in the field of health, the EU is only competent to take supplementary action. ${ }^{37}$ Available options to integrate climate change into the EU health policy are assistance in surveillance networks and using EU research calls and EU communication to respectively investigate and communicate about climate induced health risks. By contrast, when the EU has exclusive competence, which is the case with fisheries and the agricultural policy, only the EU can take action to prescribe adaptation to climate change in the implementation of these policies.

With regard to environmental law, where the EU has a shared competence with the Member States, the EU can also take legislative action. For example, the Commission proposed to amend the Environmental Impact Assessment (EIA) Directive (Directive 2011/92) to ensure that environmental impact assessments must consider climate change and where relevant take risks associated with climate change into account instead of considering only the impact of the project on the climate. ${ }^{38}$ This shared competence also implies that as long as the EU does not take action, Member States can individually amend their national legislation to insert adaptation to climate change provisions into their environmental legislation. Where the EU lacks competence, it cannot act, unless the Council unanimously decides on legislation which was proposed by the Commission and approved by the European Parliament. ${ }^{39}$

The lack of EU competence is a major problem with regard to regulation of land use. According to the 7th EAP proposal, the degradation, fragmentation and unsustainable use of land in the EU is jeopardising several key ecosystem services, threatening biodiversity and increasing Europe's vulnerability to climate change and natural disasters. ${ }^{40}$ The unanimity requirement of Article 192(2) TFEU for decision making over legislation which affects spatial planning has resulted in a dearth of binding EU land use regulation. The EU initiative to promote

37 Art. 168 TFEU.

38 EIA Directive 2011/92/EC. Despite the recent entry into force of this recodification of the EIA Directive, adaptation to climate change is not mentioned at all, whereas it is mentioned in the proposal for a revised Directive, COM (2012) 628.

39 Art. 352 TFEU.

40 Proposal for 7 th EAP, 14. 
integrated coastal zone management (ICZM) only constitutes a recommendation for this reason and the Soil Directive has remained a proposal. ${ }^{41}$ Nevertheless, the EIA, Birds, Habitats and Floods Directives ${ }^{42}$ demonstrate that the EU can regulate land use on the basis of Article 192(1) TFEU (ex Article 175(1) EC), provided that there is the political will to do so. It should be noted, however, that there is no ECJ ruling on this issue.

Yet a lack of EU competence is by no means permanent. The institutional dynamics of competence transfers between the EU and the Member States allow this situation to change. The EU can obtain competence through a revision of the Treaties, a ruling of the European courts or through the bold adoption of secondary legislation. ${ }^{43}$ In view of the impact of land use and the commitment undertaken at the RIO 20+ Conference by both the EU and the Member States to help achieve a land degradation neutral world, the Commission advocated in the 7th EAP proposal that the Council and the European Parliament reconsider the creation of a binding legal framework for land use through an EU Soil Directive. ${ }^{44}$ Apparently, the Commission will try again to regulate land use at the EU level. When it proposes new legislation, it can insert adaptation to climate change provisions with regard to land use.

If the EU opts for mainstreaming, this entails amending Directives and Regulations. That is a tough and complicated process, which takes at least several years. Given the scientific and hence economic uncertainty surrounding the impacts of climate change, it will by no means be easy to adequately mainstream adaptation to climate change into all relevant EU policies. Another problem is that revision of legislation may prompt other changes in the legislation. This is a problem for sensitive pieces of legislation. For instance a climate change inspired revision of the Nitrates Directive could well result in significantly altered provisions which reduce the ambition of the Directive in addressing nitrate pollution from agricultural sources. A similar reduction of toughness is feared in case of a revision of the Habitats Directive. Hence one can safely assume that EU involvement in adaptation will only become a success if it can also occur without amending the text of all relevant EU legislation.

\footnotetext{
41 ICZM Recommenation [2002] OJ L148/24; Proposal for a Soil Directive: COM (2006) 232 final.

42 EIA Directive 2011/92/EC, Birds Directive 2009/147/EC, Habitats Directive 92/43/EEC and Floods Directive 2007/60/EC.

43 For example, Van Ooik (2007); Pollack (2000).

44 Proposal for the 7th EAP, 15.
} 


\section{OBJECTIVE AND APPROACH OF EU LEGISLATION}

Before getting into the nitty-gritty of devising a European adaptation policy, the EU should first decide the direction adaptation should take. According to the Adaptation Strategy and the White Paper, the objective of the EU's Adaptation Framework is to improve the EU's resilience to deal with the impact of climate change. The Adaptation Strategy and the White Paper do not define what is meant by resilience. The so-called engineering approach defines resilience as return time after disturbance. ${ }^{45}$ A more dynamic, ecological approach defines resilience as the capacity of a system to absorb disturbance and reorganise while undergoing change so as to still retain essentially the same function, structure, identity and feedbacks. ${ }^{46}$ It is possible that changes are thus that a system is forced beyond the boundaries of its regime. Then it shifts into a new regime, which is governed by a different set of structures and processes. ${ }^{47}$ The concept of social-ecological resilience reflects the fact that the human influence on the resilience of ecosystems can hardly be overestimated and that both society and nature have to adapt to climate change. ${ }^{48}$

The ecological resilience literature promotes adaptive management to increase social-ecological resilience and to deal with the long-term horizon and unpredictability of climate change. ${ }^{49}$ The focus of adaptive management is on learning. Institutions which manage adaptively experiment in safe ways, monitor results, update assessments and modify their policy as new knowledge is gained..$^{50}$ The learning dimension of adaptive management also strongly values local knowledge and recognises the need to share power between different levels and sectors of government and civil society through openness and participation in decision making. ${ }^{51}$

The Adaptation Strategy and the White Paper appear to have picked up this theory, at least partially. They emphasise learning, as they propose to build a knowledge base and use the website ClimateADAPT to share and

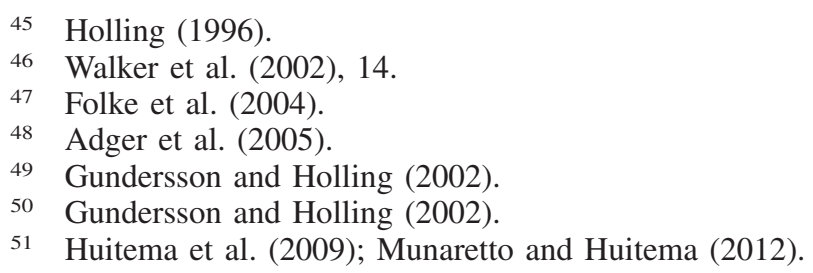


improve knowledge management..$^{52}$ However, the aim of improved monitoring of impacts and adaptation measures is to develop vulnerability indicators. Adaptive management would aim at experimenting with adaptation measures and continuous monitoring to evaluate their appropriateness and effectiveness and if need be devise alternative adaptation measures. The Adaptation Strategy hints at this approach by stating that by prioritising coherent, flexible and participatory approaches, it is cheaper to take early, planned adaptation action than to pay the price of not adapting. ${ }^{53}$ It is recognised in the literature that it is not easy to design laws which enable adaptive management. ${ }^{54}$ At the same time, adaptive management as a way of dealing with the uncertainties related to climate change can only gain traction in practice if laws endorse it. ${ }^{55}$ The problem with adaptive management is that it appears to run counter to the mission of law to provide legal certainty and stability. ${ }^{56}$ Indeed, a critical view emphasises that adaptive management should not be used as an excuse to allow the authorities an unreasonable amount of discretion to reverse or revise policies. ${ }^{57}$ This is the classical tension between legal certainty and flexibility. ${ }^{58}$ The enforceability of the commitments to adaptive management is therefore of the utmost importance. ${ }^{59}$ Moreover, it should be recalled that the law is never entirely stable. Legal rules often leave room for interpretation or discretionary room for the weighing of interests. ${ }^{60}$

Adaptive management fits in the search to innovate the law in response to the increasing complexity of governmental tasks in the field of environmental law and the need to deal with uncertainty. This has already prompted the development of a variety of approaches to supplement direct command and control regulation. ${ }^{61}$ Over the past 30 years economic instruments, voluntary arrangements and other forms of co-operation between public and private actors have become normal

52 Adaptation Strategy, 7; White Paper, 7.

53 Adaptation Strategy, 2.

54 Rühl (2012); Green et al. (2013).

55 Ibid.

56 Ibid; Ebbeson (2010).

57 Karkkainen (2004); Karkkainen (2005).

58 See also Van Holten and Van Rijswick, chapter 2 of this book.

59 Benson and Garmestani (2011); Green et al. (2013).

60 Ebbeson (2010).

61 Gunningham (2009), 184. 
policy instruments. ${ }^{62}$ Recently, European environmental law is characterised by a greater dependence on procedural rather than substantive regulatory approaches. This means that EU legislation obliges the Member States to follow specified procedures, whilst not necessarily guaranteeing particular environmental quality outcomes. In other words, regardless of the level of environmental improvement or deterioration that has been achieved, European obligations will be met if the correct regulatory procedures have been followed. ${ }^{63}$

\section{ADAPTIVE MANAGEMENT IN THE FLOODS DIRECTIVE}

Perhaps unwittingly, the European procedural approach can promote adaptive management. By way of example, this hypothesis can be tested through an analysis of the Floods Directive (FD). This Directive constitutes a prime example of this procedural approach. ${ }^{64}$ The objective of the FD is to assess and manage flood risks and to reduce the risk of adverse consequences. The Directive leaves it entirely to the Member States to set objectives and devise measures. It only provides for procedures, which include disclosure and participation obligations. ${ }^{65}$ The preamble to the FD justifies the autonomy of the Member States in the management of flood risks by pointing at the great regional variation within the EU.

The FD prescribes that the Member States must establish 'appropriate' objectives for the management of flood risks in their river basins, including coastal areas. They have to set their objectives on the basis of the flood hazard maps and flood risk maps, which the FD requires them to prepare and review every six years. Their objectives should focus on the reduction of potential adverse consequences of flooding for human health, the environment, cultural heritage and economic activity. Only if it is considered appropriate should the Member States adopt objectives to reduce the likelihood of flooding.

Consequently, different standards apply throughout a transboundary river basin. For instance, Dutch safety standards in the Rhine basin are up to ten times higher than German safety standards. ${ }^{66}$ These differences are caused by a different approach towards flood risks. A preventive

\footnotetext{
62 Ibid.

63 Howarth (2009).

64 Green et al. (2013); Keessen and Van Rijswick (2012).

65 Arts 9 and 10 Directive 2007/60/EC.

66 Van Pelt and Swart (2011).
} 
approach prevails in the Netherlands, while the German Länder take a damage-reduction approach. ${ }^{67}$ This difference is also visible in the flood risk strategies that are predominant in these countries. In the Netherlands, floods are considered calamities, which should be prevented, mainly by infrastructural works. By contrast, floods occur more regularly in Germany, but usually do not cause much damage due to the adapted land use and low density of people living in flood prone areas, which lowers the adverse effects of flooding. ${ }^{68}$ Other approaches which reduce the adverse effects of flooding are offering protection through flood warning systems and disaster management and resorting to recovery after floods, for instance through insurance. ${ }^{69}$

Thus the objective and the approach of the FD reflect an open and adaptive approach to deal with uncertainty and a focus on the local dimension of adaptation to increased flood risks. At the same time, the FD is so open and flexible that it does not even include exemptions to be invoked for not being able to reduce potential adverse consequences of flooding. ${ }^{70}$ After all, the FD does not oblige the Member States to achieve a certain level of risk reduction. It thus appears likely that the FD will succeed in obliging the Member States to assess flood risks and create maps and plans but will not result in State measures to reduce flood risks. ${ }^{71} \mathrm{~A}$ similar concern that proceduralisation does not bring home substantive results, has also been expressed with regard to the Water Framework Directive, after which the FD has been modelled. ${ }^{72}$

This procedural approach impacts the position of citizens. If their Member States inform them and encourage their active involvement in the planning process, can they also enforce the agreed measures? If Directives take a procedural approach like the FD, citizens cannot enforce compliance with EU standards. The Janecek case demonstrates that they can only enforce their right that the Member States establish adequate plans and programmes of measures to meet these standards. ${ }^{73}$ That is their only means to enforce compliance with the standards themselves. It should be noted that the position of citizens with regard to flood risks is even worse compared to Janecek. After all, the Janecek case was about enforcing compliance with specific EU air quality

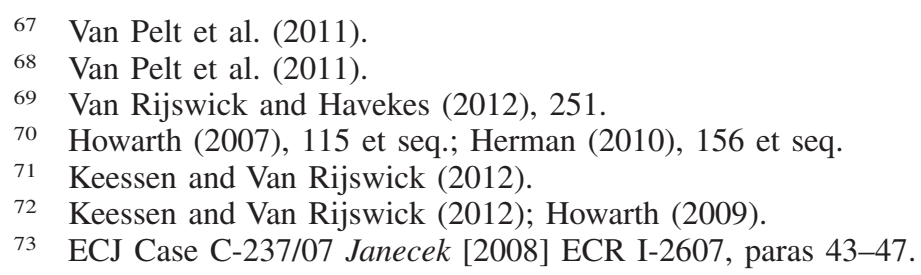


standards. Citizens who live in flood prone areas do not have an EU standard of acceptable flood risk to rely on.

People living in flood prone areas can only enforce that their Member State establish an adequate plan which includes measures to meet the objectives their State deems appropriate to reduce the adverse consequences of flooding. These objectives do not necessarily include high safety standards or aim at reduction of the likelihood of flooding. The only guarantee EU law offers concerning the appropriateness of the objectives is that they have been established on the basis of the FD procedure for the assessment of flood risks. This procedure includes transparency and public participation provisions. Nevertheless, the legal position of citizens is weak. The Directive does no more than ensure that they have the opportunity to know the flood risks. Although the FD states that flood risk plans have to include measures to achieve the objectives, it does not oblige Member States to arrive at a certain level of flood safety. Consequently, it remains a national choice which flood risk strategy will be applied.

\section{AN ADAPTATION DIRECTIVE OR AN ADAPTATION STRATEGY}

Neither the White Paper nor the proposal for the 7th EAP proposes to establish an Adaptation Framework Directive. It is no surprise then, that there is no Adaptation Directive yet. However, the Adaptation Strategy warns the Member States that the Commission might propose one. It will first try the voluntary route by providing guidelines. It will then enable benchmarking by developing an adaptation preparedness scoreboard by 2014. Finally, in 2017, the Commission will assess whether action being taken by the Member States is sufficient. If the Commission deems progress to be insufficient, it will consider without delay proposing a legally binding instrument. ${ }^{74}$

The question is of course whether the $\mathrm{EU}$ has the competence to prescribe the establishment of national adaptation strategies and measures. Article 192(1) of the environmental title of the TFEU appears sufficiently broad to provide a legal basis for such a Directive. Adaptation efforts can fall within the aims of this Article to protect the environment, human health and to promote sustainable use of natural resources. Creating a Directive with obligations to take adaptation into account in

\footnotetext{
74 Adaptation Strategy, 6.
} 
other policies resembles the integration obligation emanating from Article 11 TFEU. Such a separate Directive will be very general, as one has to deal with uncertainty and the long-term perspective of climate change impacts for all relevant policies.

An Adaptation Directive can not only be based on Articles 192 and 11 TFEU, but also on Article 196 TFEU, the legal basis for disaster risk reduction or the so-called civil protection mechanism. Under Article 196 TFEU, the Directive could be directed to prevent and protect against natural or man-made disasters through supplementary EU action. Then the EU would only be competent to take three types of action. It could then (1) support that the authorities at the national, regional and local level take measures to prevent risks and address calamities; and (2) promote operational co-operation between the Member States in case of calamities; and (3) coordinate international action in the field of disaster risk reduction. If this Article were to provide the sole legal basis for an Adaptation Directive, the Directive would not enable the realisation of all the ambitions expressed in the White Paper. It could also serve as legal basis next to the environmental Articles. Such a dual legal basis would emphasise the disaster risk reduction aspect of adaptation to climate change.

If an Adaptation Directive were to come into being, it is likely that it would have a procedural character. Similar to the FD, it could introduce the binding obligation on the Member States to plan adaptation to climate change before a specified deadline. They would be obliged to assess the risks, communicate the risks to their citizens and encourage the active participation of their citizens in the development of a plan to address these risks. It could establish an iterative cycle of developing plans and programmes of measures to reduce the adverse effects of climate change and increase resilience. The objectives could well be set by the Member States, as the situation and the impacts of climate change in the EU vary wildly. The EU would then use the Adaptation Directive to oblige all Member States to develop adaptation plans. That hardly seems exceptional, but as stated above, not all Member States currently have adaptation plans in place.

From a legal perspective, an Adaptation Directive along these lines would suffer from a number of limitations. While it would oblige the Member States to plan for adaptation, a procedural approach means that the Directive would not go further than the general obligation to take into account the need to adapt to climate change. This would entirely leave it to the Member States to determine to what extent they will adapt. The Member States will only take action to the extent that they consider that 
the state is responsible for taking adaptation measures. ${ }^{75}$ Citizens might only be entitled to information and participation in the establishment of adaptation plans and not to the achievement of concrete results, such as a reduction of flood risks or the urban heat island effect.

An Adaptation Directive could not give sufficient guidance to the various policy fields. It might even create uncertainty due to overlap with sectoral and horizontal Directives and Regulations. ${ }^{76}$ It could also not achieve the aim of the White Paper to introduce a mix of instruments to effectively deliver adaptation. That would not fit in a general Directive. Indeed, the approach in the Adaptation Strategy would be to use a Directive only to oblige the Member States to take action. So it would not be an alternative to mainstreaming adaptation into EU policies but a supplement to mainstreaming to improve the efforts of the Member States to adapt to climate change.

\section{CONCLUSIONS}

In view of the impact climate change can have on EU policies, it appears justified that the EU will become involved. Whether the EU has the competence to become involved can be answered in the affirmative. It can impose regulation through binding rules on the Member States on the basis of the environmental title and the integration principle of Article 11 TFEU. If the EU opts for mainstreaming, its competence to impose binding obligations which ensure that climate change is taken into account depends on its competence in the sectoral policy concerned. Examples of what the EU can do if it opts for mainstreaming illustrate the variation that will occur.

The Adaptation Strategy and the White Paper suggest that objective and the approach of the EU will be to increase resilience and reduce vulnerability. The EU might adhere to the adaptive management approach as it places great value on learning. This should also include experimenting, adapting policies to local knowledge and the monitoring of experimental adaptation measures. That fits with the procedural and programmatic character of recent environmental directives, of which the FD is a prime example. Perhaps not coincidentally, this Directive has been devised to address increasing flood risks in the EU, a typical climate change phenomenon. The positive elements of this Directive are the attention for assessments, iterative planning cycles to reduce adverse

\footnotetext{
75 Keessen et al. (2013).

76 See Beijen, chapter 4 in this book.
} 
flood risks, informing the public of flood risks through maps and encouraging their participation in the drafting of flood risk management plans.

However, the reliance on procedures comes at a price. It is by no means certain that flood risks or the adverse effects of flood risks will indeed diminish as a result of this Directive. After all, the Janecek case law learns that the only rights citizens can derive from such procedural Directives are procedural rights. They are entitled to assessments of flood risks, procedures which include their participation must be followed and plans must be made and communicated. Moreover, the objectives for flood risks are not set at EU level like the EU air quality norms which Janecek wanted to enforce. As long as the Member States follow the Floods Directive procedures, they are free to determine the objectives they deem appropriate.

Although a similar piece of legislation with a similar focus on procedure and a similar lack of substantive standards could be dreamed up to become an Adaptation Directive, it is unknown whether this will indeed occur. The 2009 White Paper did not propose an Adaptation Directive to supplement its ambitious mainstreaming process. By contrast, the 2013 Adaptation Strategy warns the Member States that the Commission will consider proposing an Adaptation Directive in 2017. This depends on whether the Commission will conclude from its assessment that the Member States take sufficient action to adapt to climate change or not. So the last words are not said on the choice between voluntary commitment or binding rules when it comes to adaptation to climate change in the EU.

\section{BIBLIOGRAPHY}

Adger,W.N., N.W. Arnell and E.L. Tompkins (2005), 'Successful Adaptation to Climate Change Across Scales', 15(2) Global Environmental Change, 77-86.

Becken, S. (2005), 'Harmonizing Climate Change Adaptation and Mitigation: The Case of Tourist Resorts in Fiji', 15(4) Global Environmental Change, 381-93.

Benson, M.H. and A.S. Garmestani (2011), 'Embracing Panarchy, Building Resilience and Integrating Adaptive Management through a Rebirth of the National Environmental Policy Act', 92 Journal of Environmental Management, 1420-7.

Biesbroek, G.R., R.J Swart, T.R. Carter, C. Cowan, T. Henrichts, H. Mela, M.D. Morecroft and D. Rey (2010), 'Europe Adapts to Climate Change: Comparing National Adaptation Strategies', 20 Global Environmental Change, 440-50.

Ciscar, J.C. (ed.) (2009), 'Climate change impacts in Europe', Final report of the PESETA research project, The Joint Research Centre of the European Commission.

Cole, D.H. (2011), 'From Global to Polycentric Climate Governance', 2 Climate Law, 395-413. 
Diets, S. and N. Stern (2008), 'Why Economic Analysis Supports Strong Action on Climate Change', 2(1) Review of Environmental Economics and Policy, 94-113.

Ebbeson, J. (2010), 'The Rule of Law in Governance of Complex Socio-Ecological Changes', 10 Global Environmental Change, 414-22.

Emiliou, N. (1994), 'Opening Pandora's Box: the Legal Basis of Community Measures before the Court of Justice', European Law Review, 488-507.

Folke, C., S. Carpenter, B. Walker, M. Scheffer, T. Elmqvist, L. Gunderson and C.S. Holling (2004), 'Regime Shifts, Resilience, and Biodiversity in Ecosystem Management', 35 Annual Review of Ecology, Evolution and Systematics, 557-81.

Green, O., A. Garmestani, M. Van Rijswick and A. Keessen (2013), 'EU Water Governance: Striking the Right Balance between Regulatory Flexibility and Enforcement?', 18(2) Ecology and Society, 10.

Grinsted, A., J.C. Moore and S. Jevrejeva (2013), 'Projected Atlantic Hurricane Surge Threat from Rising Temperatures', Proceedings of the National Academy of Science of the United States of America, 18 March, 201209980.

Gundersson, L.H. and C.S. Holling (eds) (2002), Panarchy: Understanding Transformations in Human and Natural Systems, Washington D.C.: Island Press.

Gunningham, N. (2009), 'Environmental Law, Regulation and Governance: Shifting Architectures', 21(2) Journal of Environmental Law, 184.

Hanger, S., C. Haug, T. Lung, L.M. Bouwer (under review), 'Mainstreaming Climate Change in Regional Development Policy: Five Insights from the 2007-2013 Programming Period'.

Herman, C. (2010), 'Will the Floods Directive Keep Our Feet Dry? Policies and Regulations in the Flemish Region and Scotland', 21(4) The Journal of Water Law, 156-66.

Holling, C.S. (1996), 'Engineering Resilience versus Ecological Resilience', in P. Schulze (ed.), Engineering with Ecological Constraints, Washington D.C.: National Academy Press.

Howarth, W. (2007), The European Community Approach to Flood Defence', 18(4) Journal of Water Law, 115-16.

Howarth, W. (2009), 'Aspirations and Realities under the Water Framework Directive: Proceduralisation, Participation and Practicalities', 21(3) Journal of Environmental Law, 391-417.

Huitema, D., E. Mostert, W. Egas, S. Moellenkamp, C. Pahl-Wostl and R. Yalcin (2009), 'Adaptive Water Governance: Assessing the Institutional Prescriptions of Adaptive (co-) Management, from a Governance Perspective and Defining a Research Agenda, 14(1) Ecology and Society, 26, available at: http://www. ecologyandsociety.org/vol14/iss1/art26/, accessed 26 November 2013.

Intergovernmental Panel on Climate Change (IPPC) (2007), Climate Change 2007: Synthesis Report, IPCC AR 4.

Jacob, D. and B. Van den Hurk (2009), 'Climate Change Scenarios at the Global and Local Scales', in L. Fulco, P. Kabat, H. van Schaik and M. van der Valk (eds), Climate Change Adaptation in the Water Sector, Oxford: Earthscan, 23.

Karkkainen, B.C. (2004), 'Whither NEPA?', 12 New York University Environmental Law Journal, 333-63

Karkkainen, B.C. (2005), 'Panarchy and Adaptive Change: Around the Loop and Back Again', 7 Minnesota Journal of Law, Science and Technology, 59-77

Keessen, A.M., J. Hamer, H.F.M.W. van Rijswick and M. Wiering, (in press), 'The Concept of Resilience from a Normative Perspective: Examples from Dutch Adaptation Strategies', Ecology and Society, 18(2): 45, available at http://www. ecologyandsociety.org/vol18/iss2/art45. 
Keessen, A.M. and H.F.M.W. van Rijswick (2012), 'Adaptation to Climate Change in European Water Law and Policy', 8 Utrecht Law Review, 3.

Knook, A. (2004), 'Guns and Tobacco. The Effects of Interstate Trade Case Law on the Vertical Division of Powers' 11(4) Maastricht Journal of European and Comparative Law, 347.

Mendelsohn, R. (2008), 'Is the Stern Review an Economic Analysis?', 2(1) Review of Environmental Economics and Policy, 45-60.

Munaretto, S. and D. Huitema (2012), 'Adaptive Comanagement in the Venice Lagoon? An Analysis of Current Water and Environmental Management Practices and Prospects for Change', 2 Ecology and Society, 19, available at: http:// www.ecologyandsociety.org/vol17/iss2/art19/, accessed 26 November 2013.

Van Ooik, R.H. (2007), 'The European Court of Justice and the Division of Competence in the European Union', in D. Obradovic and N. Lavranos (eds), Interface between EU Law and National Law, Groningen: Europa Law Publishing, $11-40$.

Van Pelt, S.C. and R.J. Swart (2011), 'Climate Change Risk Management in Transnational River Basins: the Rhine', 25 Water Resource Management, 3837-61.

Pethick, J.S. and S. Crooks (2000), 'Development of a Coastal Vulnerability Index: A Geomorphological Perspective', 27 Environmental Conservation, 359-67.

Pollack, M.A. (2000), 'The End of Creeping Competence? EU Policy Making Since Maastricht', 38(3) Journal of Common Market Studies, 519-38.

Van Rijswick, H.F.M.W. and H. Havekes (2012), European and Dutch Water Law, Groningen: Europa Law Publishing.

Rühl, J.B. (2012), 'Panarchy and the Law', 17(3) Ecology and Society, 31.

Schreurs, M.A. (2007), 'Multi-Level Reinforcement: Explaining European Union Leadership in Climate Change Mitigation', 7(4) Global Environmental Politics, 19-46.

Schunz, S. (2012), 'The EU in the United Nations Climate Change Regime', in J. Wouters, H. Bruyninckx, S. Basu and S. Schunz (eds), The European Union and Multilateral Governance, Basingstoke: Palgrave Macmillan, 191-213.

Termeer, C., A. Dewulf, H. van Rijswick, A. van Buuren, D. Huitema, S. Meijerink, T. Rayner and M. Wiering (2011), 'The Regional Governance of Climate Adaptation: A Framework for Developing Legitimate, Effective and Resilient Governance Arrangements', 2 Climate Law, 159-79.

Walker, B, S. Carpenter, J. Andries, N. Abel, G. Cumming, M. Janssen, L. Lebel, J. Norberg and G. Peterson (2002), 'Resilience Management in Social-Ecological Systems: A Working Hypothesis for a Participatory Approach', 6(1) Conservation Ecology, 14. 